\title{
Nanoelectrocatalyst Anode for Direct Methanol Fuel Cells: Fabrication and Electrochemical Characterization of Graphene/Pt-Ni
}

\author{
Safaa A. Elsherif, M.F. Zawrah", N.A. Abdel Ghany", F. A. \\ Taher $^{* *}$, R.M. Khattab ${ }^{*}$ and M. M. El-Fass ${ }^{* *}$ \\ Physical Chemistry Dept. "Refractory and Ceramics Dept., \\ National Research Centre and ${ }^{* *}$ Chemistry Dept., Faculty of \\ Science (Girls), AL-Azhar University, Cairo, Egypt.
}

\begin{abstract}
D T-BASED catalysts are promising anodic catalysts for direct methanol fuel cells (DMFCs). However, the slow reaction kinetics, $\mathrm{CO}$ poisoning and high cost of $\mathrm{Pt}$, reduce the performance of DMFCs. In this study, polyol synthesis as one-step simple and economic method was applied to prepare graphene supported $\mathrm{Pt}-\mathrm{Ni}$ catalysts $(\mathrm{G} / \mathrm{Pt}-\mathrm{Ni})$. The reduction of graphene oxide to graphene and the deposition of well-dispersed Pt-Ni alloy nanoparticles on graphene were achieved simultaneously in ethylene glycol which acts as reducing agent and solvent as well. Four catalysts containing different $\mathrm{Ni}$ content were synthesized, i.e. $\mathrm{G} / \mathrm{Pt}, \mathrm{G} / \mathrm{Pt}_{1}-\mathrm{Ni}_{1}, \mathrm{G} / \mathrm{Pt}_{2}-\mathrm{Ni}_{1}$ and $\mathrm{G} / \mathrm{Pt}_{3}-$ $\mathrm{Ni}_{1}$. The total metals loading in all batches were 30 wt. $\%$. The prepared catalysts were characterized by X-ray diffraction (XRD), transmission electron microscope (TEM) and energy-dispersive X-ray spectroscopy (EDX). The electrocatalytic activities towards methanol oxidation reaction (MOR) have been investigated using cyclic voltammetry $(\mathrm{CV})$ and chronoamperometry $(\mathrm{CA})$ in $0.5 \mathrm{M} \mathrm{H}_{2} \mathrm{SO}_{4}$ containing $1 \mathrm{M} \mathrm{CH}_{3} \mathrm{OH}$. The $\mathrm{G} / \mathrm{Pt}-\mathrm{Ni}$ showed superior mass and specific activities, good poison tolerance and enhanced stability toward MOR compared to that of G/Pt. The G/Pt $\mathrm{Pi}_{1}$ catalyst showed the highest electrocatalytic activity and stability toward MOR, better tolerance to the intermediate species, and favors long-term application as an anode material for DMFCs.
\end{abstract}

Keywords: Methanol oxidation, DMFCs, Graphene and Cyclic voltammetry.

With the increase of demands for power and energy for portable devices which require high quantity of energy and long life time batteries, many researchers are focusing on diverse energy harvesting systems such as fuel cells ${ }^{(1)}$. Among different types of fuel cells, direct methanol fuel cells (DMFCs) are considered as a promising candidate for power sources, because of their high energy density, low operating temperature, simple feed strategy, system simplification, low cost, easy handling and storing of renewable liquid fuel ${ }^{(2)}$. The commercial applications of DMFCs are still hindered by some technical barriers such as the methanol crossover from anode to cathode through proton exchange membrane, high cost and the poor kinetic energy of the anodic reaction ${ }^{(3-4)}$. To overcome the poor kinetic energy of the anodic reaction, platinum is used as the best single

${ }^{\#}$ Corresponding Author Email : na.abdel@nrc.sci.eg 
metal anode catalyst in terms of high catalytic activity for methanol oxidation reaction $(\mathrm{MOR})^{(5)}$. However, pure platinum has drawbacks such as serious poisoning by $\mathrm{CO}$ adsorption, produced as intermediates during the MOR process, as well as its undesirable high $\operatorname{cost}^{(6)}$. The efficient way to reduce CO poisoning is to use binary or ternary catalysts by introducing new components such as $\mathrm{Ru}, \mathrm{Sn}, \mathrm{Pd}, \mathrm{Ni}$ and $\mathrm{Co}$ with $\mathrm{Pt}$, which promote the oxidation of $\mathrm{CO}$ on $\mathrm{Pt}$ at lower potential via the bi-functional mechanism ${ }^{(7,8)}$. The binary catalyst usually consists of a primary metal that has a high catalytic activity and a secondary metal that can enhance the catalytic activity and prevent poisoning problems ${ }^{(9,10)}$. The common anode catalyst for DMFC is PtRu, which has significant activity towards methanol oxidation, due to the Ru high activity towards water dissociation that facilitates the removal of adsorbed CO species. However, $\mathrm{PtRu}$ still has some drawbacks due to its high cost and limited supplies ${ }^{(11,13)}$. As a result, alloying $\mathrm{Pt}$ with low cost metals alternatives to $\mathrm{Ru}$ especially the transition metals can change the electronic configuration of $\mathrm{Pt}$ and weaken the interaction between Pt-CO intermediates, providing $\mathrm{M}-\mathrm{OH}$ sites at lower potentials, and thereby enhancing its catalytic performance and improve the stability ${ }^{(14)}$. On the other hand, the presence of a more abundant second element could contribute to decrease the costs associated with $\mathrm{Pt}^{(15)}$. Also, for the efficient utilization of high cost noble metals, a suitable support materials are usually used with the electrocatalyst. Carbon materials such as activated carbons, graphite nanofibers ${ }^{(17)}$ and carbon nanotubes $(\mathrm{CNT})^{(18)}$ have been studied as catalyst support materials. Among these materials graphene, which consists of two dimensional layers of carbon with one-atomic thickness is a particularly promising catalyst support material. Unique properties of graphene include high specific surface area, superior mechanical properties, high flexibility and excellent conductivity resulting in an ideal candidate as a support in DMFCs ${ }^{(19-21)}$.

In this work, a simple one-step method was used to prepare graphene supported Pt-Ni nanocatalytic anode materials (G/Pt-Ni) by polyol method. The reduction of graphene oxide to graphene and dispersion of $\mathrm{Pt}-\mathrm{Ni}$ nanoparticles on graphene were achieved simultaneously in ethylene glycol, which acts as a reducing agent and a solvent as well. Compared to the multistep method, this method is greener, safer and more convenient because of the simple operation, short production cycle, and low energy consumption.

\section{Materials}

\section{Experimental}

Graphite powder $<20 \mu \mathrm{m}$, Chloroplatinic acid $\left(\mathrm{H}_{2} \mathrm{Cl}_{6} \mathrm{Pt} \cdot \mathrm{xH}_{2} \mathrm{O}, \geq 99.9 \%\right)$ and Nafion ${ }^{\circledR} 117$ solution (5\%) were purchased from (Sigma Aldrich). Sulfuric acid $\left(\mathrm{H}_{2} \mathrm{SO}_{4}, 99 \%\right)$ from (Sham lab), Sodium nitrate and Ethylene glycol, $\left(\mathrm{NaNO}_{3}\right.$ and $\mathrm{C}_{2} \mathrm{H}_{6} \mathrm{O}_{2}, 99 \%$ ) from ( $\mathrm{S} d$ fine-Chem Limited), Potassium permanganate $\left(\mathrm{KMnO}_{4}, 99 \%\right)$ from (Arabic Laboratory Equipment Co.), Hydrogen peroxide $\left(\mathrm{H}_{2} \mathrm{O}_{2}, 30 \% \mathrm{~W} / \mathrm{V}\right)$ from (LOBA Chemie), and Nickel nitrate $\left(\mathrm{Ni}\left(\mathrm{NO}_{3}\right)_{2} \cdot 6 \mathrm{H}_{2} \mathrm{O}\right.$, 98-102\%) from (Bio Basic INC).

Egypt. J. Chem. 58, No. 4 (2015) 
Preparation of graphene oxide (GO)

Graphene oxide was prepared by chemical oxidation of graphite powder according to the modified Hummers method ${ }^{(22)}$. First, $2 \mathrm{~g}$ graphite powder and 1 g NaNO 3 were mixed with $140 \mathrm{ml}$ concentrated $\mathrm{H}_{2} \mathrm{SO}_{4}$ and stirred for $20 \mathrm{~min}$ in a conical flask within an ice bath. Then $6 \mathrm{~g}$ of $\mathrm{KMnO}_{4}$ was added gradually into the mixture under continuous stirring for additional 15 min, to obtain a blackgreen suspension. Then the solution was kept at $35^{\circ} \mathrm{C}$ for $1 \mathrm{hr}$. Distilled water $(92 \mathrm{ml})$ was slowly added and the temperature was increased to $98{ }^{\circ} \mathrm{C}$, the mixture was maintained at that temperature for $30 \mathrm{~min}$. The reaction was terminated by adding distilled water $(260 \mathrm{ml})$ followed by adding $30 \% \mathrm{H}_{2} \mathrm{O}_{2}$ solution $(20 \mathrm{ml})$. The color of the solution changed to brilliant yellow, indicating the oxidation of pristine graphite to graphite oxide. Then, the mixture was washed with $600 \mathrm{ml} 10 \% \mathrm{HCl}$ to remove metal ions. Finally, the product was washed repeatedly with distilled water until neutralization $(\mathrm{pH} 7)$ is obtained. The sample of graphite oxide was collected after drying in air. To prepare graphene oxide, the as-obtained graphite oxide was re-dispersed in distilled water, and the exfoliation of graphite oxide to generate GO sheets was done by ultrasonication for $30 \mathrm{~min}$.

\section{Preparation of graphene supported Pt-Ni (G/Pt-Ni)}

Three different ratios of G/Pt-Ni, (Pt:Ni; (3:1), (2:1) and (1:1)) nanocatalysts were synthesized by simple one-step polyol method and the following procedure was adapted. The as-obtained GO (6 mg/ml) $22 \mathrm{ml}$ was first mixed with $60 \mathrm{ml}$ of Ethylene glycol (EG) and sonicated for $16 \mathrm{~min}$. Subsequently, different volumes of $\mathrm{H}_{2} \mathrm{Cl}_{6} \mathrm{Pt} \cdot \mathrm{xH}_{2} \mathrm{O}(10 \mathrm{mg} / \mathrm{ml})$ and $\mathrm{Ni}\left(\mathrm{NO}_{3}\right)_{2} \cdot 6 \mathrm{H}_{2} \mathrm{O}(10 \mathrm{mg} / \mathrm{ml})$ were added and stirred for $2 \mathrm{hr}$ to get a homogeneous dispersion. After that, the mixture was heated under continuous stirring and refluxed at $80^{\circ} \mathrm{C}$ for $5 \mathrm{hr}$. After the reaction, the black solution was left to cool down to room temperature, then centrifuged and washed with excess distilled water several times. Finally, the sample was dried for $24 \mathrm{hr}$ at $80^{\circ} \mathrm{C}$ in air. For the purpose of comparison, the graphene supported $\mathrm{Pt}$ (G-Pt) was produced by the same method without the addition of $\mathrm{Ni}\left(\mathrm{NO}_{3}\right)_{2} \cdot 6 \mathrm{H}_{2} \mathrm{O}$.

\section{Characterization of G/Pt-Ni nanocatalysts}

The crystal structure of the prepared catalysts were examined by X-ray diffraction (XRD, XPERT- PRO- PANalytical) with $\mathrm{Cu} \mathrm{K} \alpha$ radiation $(\lambda=1.54$ $\mathrm{A}^{\circ}$ ). The morphology of the catalysts was confirmed by high-resolution TEM (HRTEM), which was carried out using JOEL (JEM-2100) electron microscope operating at an accelerating voltage of $120 \mathrm{kV}$. The loading and the composition of the Pt-Ni nanostructures on the graphene were analyzed by Energy-dispersive $\mathrm{X}$-ray spectroscopy (EDX), fixed on the scanning electron microscope (SEM, Quanta FEG250).

\section{Electrochemical measurements}

The electrochemical measurements were carried out with an Autolab 302N electrochemical workstation (Metrohm). A conventional three-electrode system was 
used with a glassy carbon (GC) electrode ( $5 \mathrm{~mm}$ in diameter) as a working electrode. A coiled Pt wire and $\mathrm{Ag} / \mathrm{AgCl}$ electrode $(3 \mathrm{M} \mathrm{KCl})$ were used as a counter electrode and a reference electrode, respectively. Prior to use, the GC electrode was polished with $0.3 \mu \mathrm{m}$ alumina to create a mirror surface. The electrode was then sonicated with distilled water for $\sim 5 \mathrm{~min}$ and dried under ambient temperature. The catalyst ink was prepared by dispersing $5 \mathrm{mg}$ of the catalyst powder in $0.5 \mathrm{ml} \mathrm{Nafion}{ }^{\circledR} 117$ solution $(1 \%)$ by ultrasonication for $30 \mathrm{~min}$. A $4 \mu \mathrm{L}$ suspension of the catalyst $(10$ $\mathrm{mg} / \mathrm{ml}$ ) was cast onto the surface of the electrode with a micropipette. Finally, the working electrode was dried at $60{ }^{\circ} \mathrm{C}$ for $10 \mathrm{~min}$ and left to be cooled down.

The electrochemically active surface area (ECSA) and electrocatalytic activity of the catalysts toward MOR were measured by cyclic voltammetry in $\left(0.5 \mathrm{M} \mathrm{H}_{2} \mathrm{SO}_{4}\right)$ and $\left(0.5 \mathrm{M} \mathrm{H}_{2} \mathrm{SO}_{4}+1 \mathrm{M} \mathrm{CH}_{3} \mathrm{OH}\right)$ electrolyte, respectively, in the potential range from -0.2 to $1.3 \mathrm{~V}$ vs $\mathrm{Ag} / \mathrm{AgCl}$ with a scan rate of $100 \mathrm{mV} / \mathrm{s}$ at room temperature. The electrolyte was de-aerated before each experiment by purging it with $\mathrm{N}_{2}$ gas for about $30 \mathrm{~min}$, and then $\mathrm{N}_{2}$ gas was purged over the solution during the measurements.

$X$-ray diffraction $(X R D)$

\section{Results and Discussion}

Figure 1 illustrates the XRD patterns of $\mathrm{GO}, \mathrm{G}-\mathrm{Pt}, \mathrm{G} / \mathrm{Pt}_{3}-\mathrm{Ni}_{1}, \mathrm{G} / \mathrm{Pt}_{2}-\mathrm{Ni}_{1}$, and $\mathrm{G} / \mathrm{Pt}_{1}-\mathrm{Ni}_{1}$ catalysts. It exhibits the structural information and phase identification for bulk catalyst nanoclusters together with the graphene support. All samples exhibit diffraction peak at $\sim 25.22^{\circ}$, which is related to the (002) structure reflection of the graphene, indicating the successful conversion of initial GO to graphene. Its intensity is relatively the same in all samples. The other three peaks at $2 \theta$ values of $\sim 40^{\circ}, 47^{\circ}$ and $68^{\circ}$ are corresponding to the (111), (200) and (220) planes of face-centered cubic (fcc) crystalline Pt. No peaks corresponding to fcc $\mathrm{Ni}$ are detected, but all peaks corresponding to $\mathrm{Pt}$ are shifted to smaller $2 \theta$ values. This indicates the contraction of Pt lattice, which is an evidence for Pt-Ni alloy formation ${ }^{(23)}$. The average crystallite size is about 1-3 nm, as calculated from Debye-Scherrer equation and shown in Table 1.

\section{Transmission electron microscope (TEM)}

Figure 2(a-d) shows HR-TEM images of the as prepared catalysts. It can be seen that the graphene and Pt-Ni nanoparticles are highly homogeneous and Pt$\mathrm{Ni}$ is well dispersed on graphene. This uniform dispersion of nanoparticles may be due to the effect of using ethylene glycol as a solvent and reducing agent which prevents the aggregation of $\mathrm{Pt}-\mathrm{Ni}$ nanoparticles and the restacking of reduced GO by the formation of graphene nanoparticle catalyst ${ }^{(24)}$. As shown in Fig. 2, G/Pt (a) and $\mathrm{G} / \mathrm{Pt}_{3}-\mathrm{Ni}_{1}$ (b) catalysts have larger particle size than $\mathrm{G} / \mathrm{Pt}_{2^{-}}$ $\mathrm{Ni}_{1}$ (c) and $\mathrm{G} / \mathrm{Pt}_{1}-\mathrm{Ni}_{1}$ (d) catalysts. The average particle size is about 1-3 nm which is in a good agreement with XRD calculations (Table 1).

Egypt. J. Chem. 58, No. 4 (2015) 
TABLE 1. EDX composition and comparison of the particle size of the catalysts.

\begin{tabular}{|c|c|c|c|}
\hline $\begin{array}{c}\text { Catalyst } \\
\text { type }\end{array}$ & $\begin{array}{c}\text { XRD } \\
\text { Crystallite } \\
\text { (size (nm }\end{array}$ & $\begin{array}{c}\text { TEM Particle } \\
\text { size (nm) }\end{array}$ & $\begin{array}{c}\text { EDX } \\
\text { Metals } \\
\text { composition }\end{array}$ \\
\hline $\mathrm{G} / \mathrm{Pt}$ & 1.53 & 1.85 & --- \\
$\mathrm{G} / \mathrm{Pt}_{3}-\mathrm{Ni}_{1}$ & 2.3 & 1.63 & $73.6: 26.4$ \\
$\mathrm{G} / \mathrm{Pt}_{2}-\mathrm{Ni}_{1}$ & 1.7 & 1.30 & $67: 33$ \\
$\mathrm{G} / \mathrm{Pt}_{1}-\mathrm{Ni}_{1}$ & 1.54 & 1.22 & $49: 51$ \\
\hline
\end{tabular}

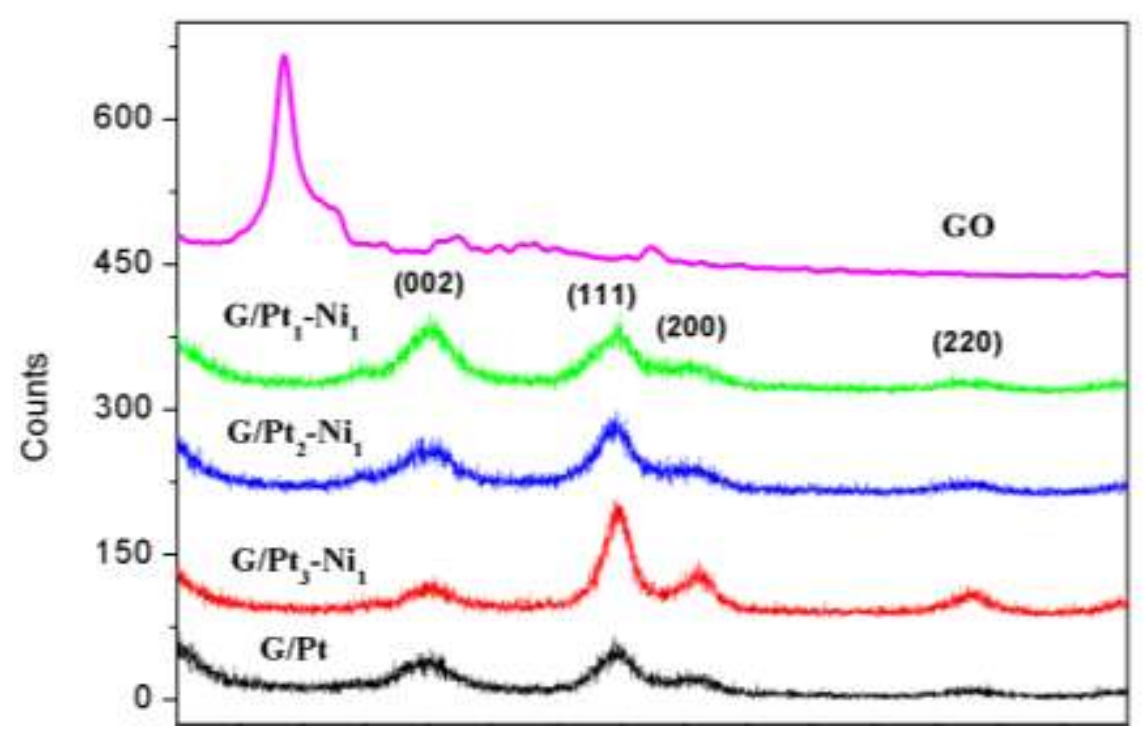

Fig. 1. XRD analysis of the G/Pt, G/Pt ${ }_{3}-\mathrm{Ni}_{1}, \mathrm{G} / \mathrm{Pt}_{2}-\mathrm{Ni}_{1}, \mathrm{G} / \mathrm{Pt}_{1}-\mathrm{Ni}_{1}$ catalysts, and $\mathrm{GO}$.

Energy dispersive $X$-ray spectroscopy $(E D X)$

The metal loading on graphene for the nanocatalysts was analyzed and confirmed by EDX analysis. Pt:Ni atomic ratio obtained by EDX analysis for all catalysts is listed in Table 1. The expected total amount of metal loading (Pt-Ni) could be achieved. This amount is nearly the same as the precursors involved in the reaction mixtures. This indicates the complete reduction of precursors at the proposed experimental conditions. Figure $3(\mathrm{a} \& \mathrm{~b})$ shows qualitative EDX analysis of $\mathrm{G} / \mathrm{Pt}$ and $\mathrm{G} / \mathrm{Pt}_{1}-\mathrm{Ni}_{1}$ catalysts, respectively. The expected composition of catalysts is confirmed by the observation of $\mathrm{C}, \mathrm{O}, \mathrm{Pt}$ and $\mathrm{Ni}$. The presence of $\mathrm{O}$ seems to be due to the incomplete reduction of $\mathrm{GO}$ and/or the presence of some oxidized metals. 

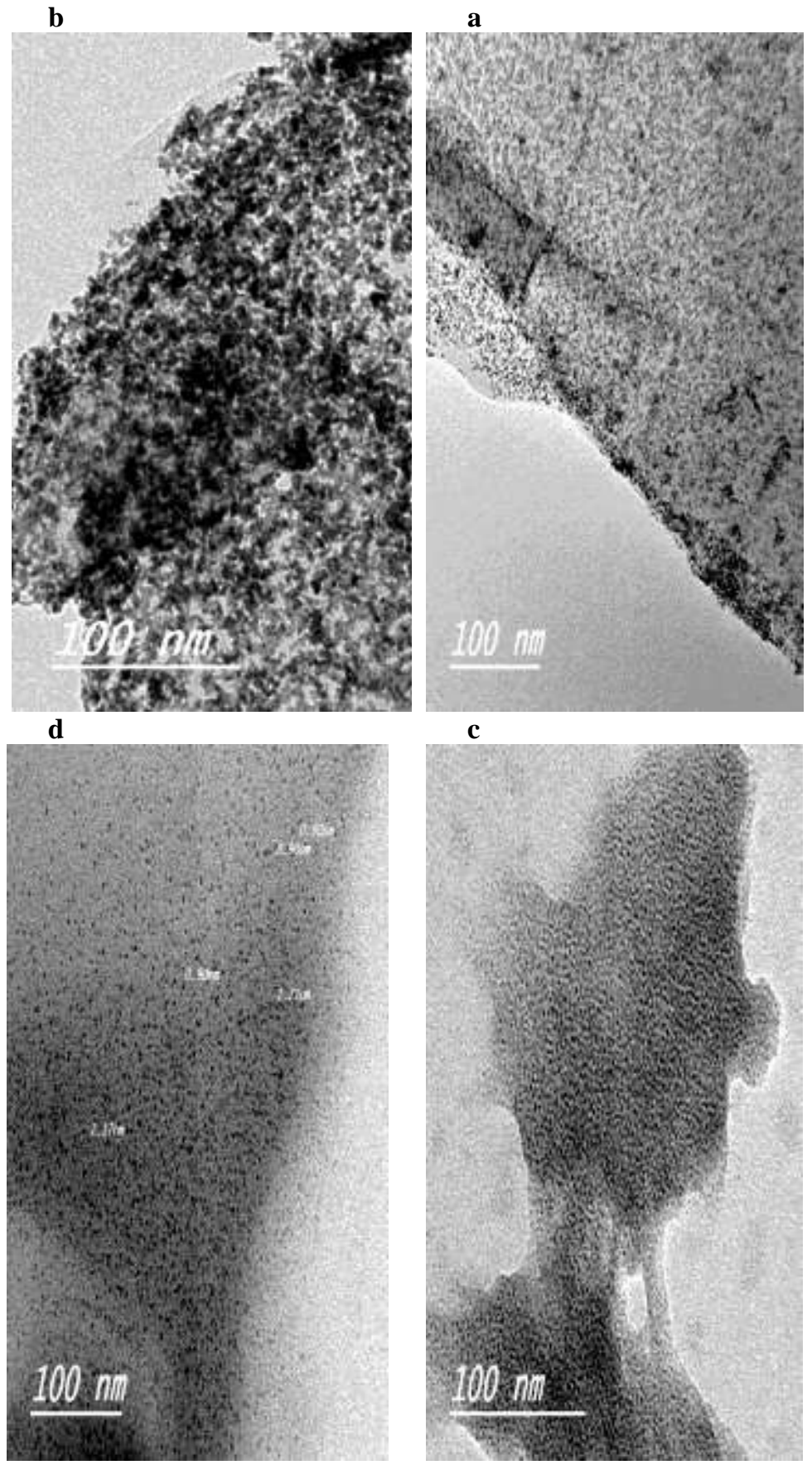

Fig. 2. HR-TEM images of (a) G/Pt, (b) G/Pt $\mathbf{P t}_{3}-\mathrm{Ni}_{1}$, (c) G/Pt $-\mathrm{Ni}_{2}$, and (d) G/Pt $\mathbf{P t}_{1}-\mathrm{Ni}_{1}$ catalysts.

Egypt. J. Chem. 58, No. 4 (2015) 
b

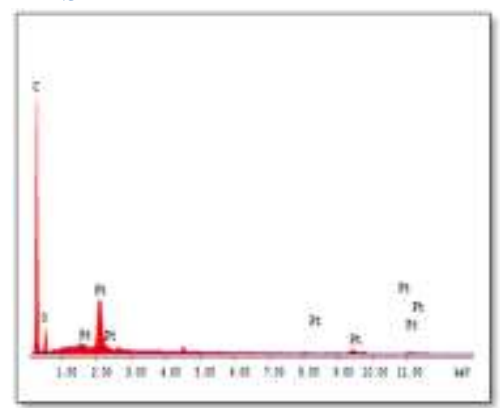

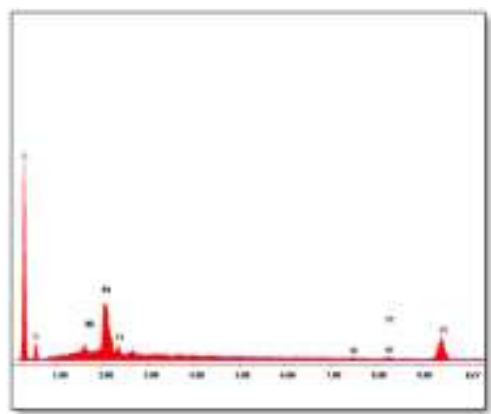

Fig. 3. EDX spectrum of (a) G/Pt and (b) $\mathrm{G} / \mathrm{Pt}_{\mathbf{1}}-\mathrm{Ni}_{1}$ catalysts.

Cyclic voltammetry $(\mathrm{CV})$

Figure 4 depicts $\mathrm{CV}$ data of the synthesized catalysts. The characteristic peaks for the formation and reduction of $\mathrm{Pt}$ oxide were observed in the potential region of $0.6-0.9 \mathrm{~V}$ and $0.3-0.7 \mathrm{~V}$, respectively. Also, in the region of -0.2-0.1 V, the hydrogen under potential deposition (Hupd) peaks from polycrystalline Pt are clearly indicated ${ }^{(25)}$. The ECSA for the catalysts was calculated according to the formula

$$
\mathrm{ECSA}=(\mathrm{Q}) /\left(\mathrm{W}_{\mathrm{Pt}} * 2.1\right)
$$

where $\mathrm{Q}$ represents the integrated charge of the Hupd peaks in Coulomb, $\mathrm{W}_{\mathrm{Pt}}$ is the platinum loading in $\mathrm{g}$ and $2.10 \mathrm{C} / \mathrm{m}^{2}$ is a constant that represents charge required to oxidize a monolayer of $\mathrm{H}_{2}$ on $\mathrm{Pt} 0^{(26)}$. The calculated ECSA values were found to be 9, 17 and $10 \mathrm{~m} / \mathrm{g}$ for $\mathrm{G} / \mathrm{Pt}_{3}-\mathrm{Ni}_{1}, \mathrm{G} / \mathrm{Pt}_{2}-\mathrm{Ni}_{1}$ and $\mathrm{G} / \mathrm{Pt}_{1}-\mathrm{Ni}_{1}$ catalysts, respectively (Table 1). ECSA of G/Pt catalyst is $24 \mathrm{~m}^{2} / \mathrm{g}$ which is higher than those of other catalysts. These lower values might be due to two reasons, the first one is the larger amount of $\mathrm{Pt}$ in $\mathrm{G} / \mathrm{Pt}$ catalyst and the second is that exposure of $\mathrm{Pt}$ to the surface of catalyst particles is hindered by incorporation of $\mathrm{Ni}^{(27)}$.

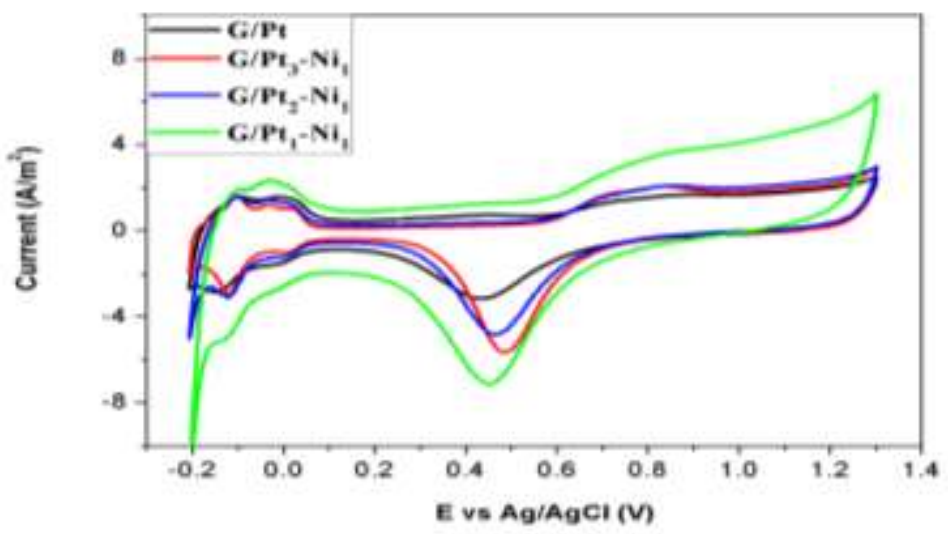

Fig. 4. Cyclic voltammetric response of $\mathrm{G} / \mathrm{Pt}, \mathrm{G} / \mathrm{Pt}_{3}-\mathrm{Ni}_{1}, \mathrm{G} / \mathrm{Pt}_{2}-\mathrm{Ni}_{1}$, and $\mathrm{G} / \mathrm{Pt}_{1}-\mathrm{Ni}_{1}$ catalysts in $0.5 \mathrm{M} \mathrm{H}_{2} \mathrm{SO}_{4}$ at scan rate of $100 \mathrm{mV} / \mathrm{s}$.

Egypt. J. Chem. 58, No. 4(2015) 
The electrocatalytic performance of the catalysts is shown in Fig. 5. It is observed that the anodic peak at $\sim 0.72 \mathrm{~V}$ in the forward sweep and that at $0.4 \mathrm{~V}$ in the backward sweep are related to the oxidation of methanol and intermediates, respectively. The forward scan is attributed to methanol oxidation and forming $\mathrm{Pt}$ adsorbed carbonaceous intermediates such as $\mathrm{CO}$ and $\mathrm{CO}_{2}$ leading to the loss of activity of the electrocatalyst. The reactions can be expressed as follows ${ }^{(28)}$.

$$
\begin{aligned}
& \mathrm{Pt}+\mathrm{CH}_{3} \mathrm{OH} \rightarrow \mathrm{Pt}-\mathrm{CO}_{\mathrm{ads}}+4 \mathrm{H}^{+}+4 \mathrm{e}^{-} \\
& \mathrm{CH}_{3} \mathrm{OH}+\mathrm{H}_{2} \mathrm{O} \rightarrow \mathrm{CO}_{2}+6 \mathrm{H}^{+}+6 \mathrm{e}^{-} \\
& \mathrm{Pt}-\mathrm{CO}_{\mathrm{ads}}+\mathrm{H}_{2} \mathrm{O} \rightarrow \mathrm{Pt}+\mathrm{CO}_{2}+2 \mathrm{H}^{+}+2 \mathrm{e}^{-}
\end{aligned}
$$

The backward oxidation peak (reaction (3)) can be attributed to the oxidation of the adsorbed carbonaceous species to $\mathrm{CO}_{2}$.

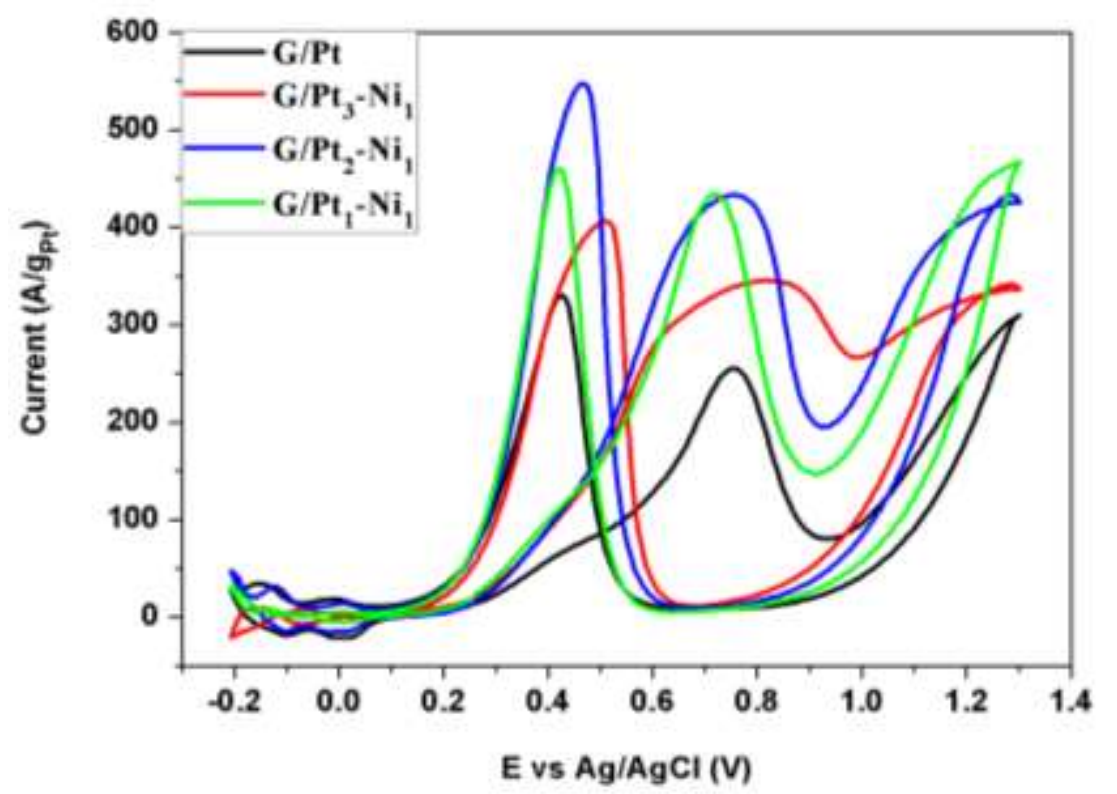

Fig. 5. Mass activity of $\mathrm{G} / \mathrm{Pt}, \mathrm{G} / \mathrm{Pt}_{3}-\mathrm{Ni}_{1}, \mathrm{G} / \mathrm{Pt}_{2}-\mathrm{Ni}_{1}$, and $\mathrm{G} / \mathrm{Pt}_{1}-\mathrm{Ni}_{1}$ catalysts in $0.5 \mathrm{M}$ $\mathrm{H}_{2} \mathrm{SO}_{4}$ containing $1 \mathrm{M} \mathrm{CH} \mathrm{CH}_{3} \mathrm{OH}$ at scan rate of $100 \mathrm{mV} / \mathrm{s}$, the current normalized to the Pt loading.

The mass activity of $\mathrm{G} / \mathrm{Pt}, \mathrm{G} / \mathrm{Pt}_{3}-\mathrm{Ni}_{1}, \mathrm{G} / \mathrm{Pt}_{2}-\mathrm{Ni}_{1}$ and $\mathrm{G} / \mathrm{Pt}_{1}-\mathrm{Ni}_{1}$ is 239,330 , 428 and $434 \mathrm{~A} / \mathrm{g}_{\mathrm{Pt}}$, respectively, is shown in Fig. 5. All catalysts containing Ni have higher catalytic activity than G/Pt. As shown in Fig. 6a, the specific activity for $\mathrm{G} / \mathrm{Pt}_{3}-\mathrm{Ni}_{1}$ is $41 \mathrm{~A} / \mathrm{m}^{2}, \mathrm{G} / \mathrm{Pt}_{2}-\mathrm{Ni}_{1}$ is $26 \mathrm{~A} / \mathrm{m}^{2}$ and $\mathrm{G} / \mathrm{Pt}_{1}-\mathrm{Ni}_{1}$ is $46 \mathrm{~A} / \mathrm{m}^{2}$, which is $4,2.5$ and 4.5 times higher than $\mathrm{G} / \mathrm{Pt}\left(11 \mathrm{~A} / \mathrm{m}^{2}\right)$. For both terms of mass activity and specific activity, $\mathrm{G} / \mathrm{Pt}_{1}-\mathrm{Ni}_{1}$ has the highest values, which seems to be due to the high content of $\mathrm{Ni}$.

Egypt. J. Chem. 58, No. 4 (2015) 

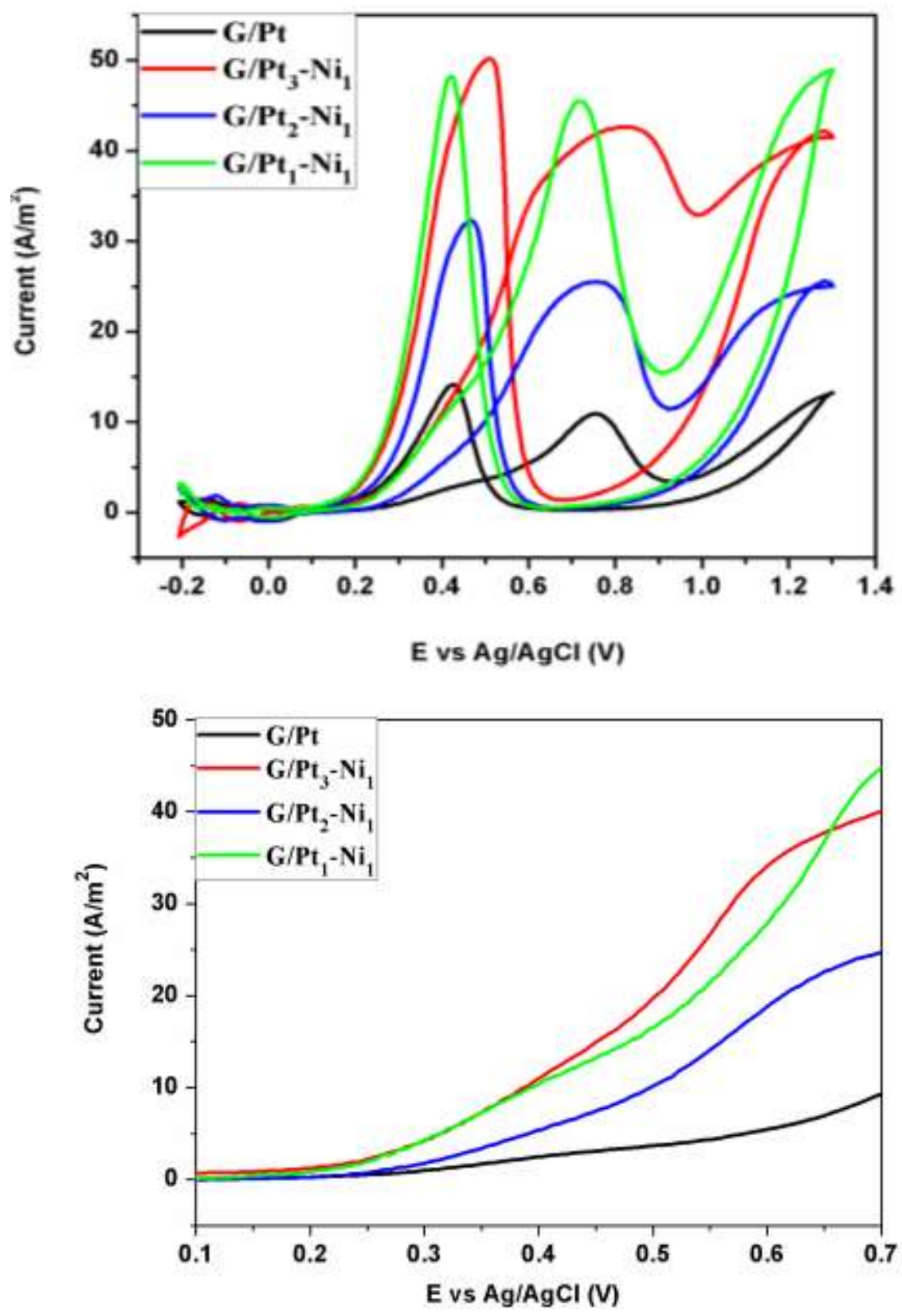

Fig. 6 (a,b). Specific activity of $\mathrm{G} / \mathrm{Pt}, \mathrm{G} / \mathrm{Pt}_{3}-\mathrm{Ni}_{1}, \mathrm{G} / \mathrm{Pt}_{2}-\mathrm{Ni}_{1}$, and $\mathrm{G} / \mathrm{Pt}_{1}-\mathrm{Ni}_{1}$ catalysts in $0.5 \mathrm{M} \mathrm{H}_{2} \mathrm{SO}_{4}$ containing $1 \mathrm{M} \mathrm{CH} \mathrm{CH}_{3} \mathrm{OH}$ at scan rate of $100 \mathrm{mV} / \mathrm{s}$, the current normalized by electrochemically active area. 
The ratio of forward anodic peak current $\left(\mathrm{I}_{\mathrm{f}}\right)$ to backward anodic peak current $\left(\mathrm{I}_{\mathrm{b}}\right)$ is considered an important index for evaluating the activity of methanol oxidation and the poison tolerance of Pt based catalysts in $\mathrm{MOR}^{(29)}$. The higher $I_{f} / I_{b}$ value the more effective removal of poisoning species on the catalyst surface which means a relatively complete oxidation of methanol and producing carbon dioxide $^{(30)}$. According to reaction (3), this ratio reflects the amount of methanol oxidized to carbon dioxide to the amount of carbon monoxide. In other words, this ratio essentially reflects the fraction of catalyst surface that is not poisoned by $\mathrm{CO}$ adsorption. As shown in Table 2 , the $\mathrm{I}_{\mathrm{f}} / \mathrm{I}_{\mathrm{b}}$ value of the $\mathrm{G} / \mathrm{Pt}_{1}-\mathrm{Ni}_{1}$ catalyst is $\sim 0.94$ which is higher than G/Pt3-Ni1 $\sim$ 0.84), G/Pt2-Ni1 $(\sim 0.79)$ and the G/Pt ( 0.77), suggesting that the G/Pt1-Ni1 catalyst surface has less carbonaceous species accumulation and therefore has good poison tolerance.

TABLE 2. Comparison of the electrochemical activities of the catalysts.

\begin{tabular}{|l|c|c|c|c|c|}
\hline Catalyst type & $\begin{array}{c}\text { ECSA } \\
\left(\mathbf{m}^{2} / \mathbf{g}\right)\end{array}$ & $\begin{array}{c}\text { Current } \\
\text { density } \\
\left(\mathbf{A} / \mathbf{g}_{\mathbf{P t}}\right)\end{array}$ & $\begin{array}{c}\text { Current } \\
\mathbf{d e n s i t y} \\
\left(\mathbf{A} / \mathbf{m}^{\mathbf{2}}\right)\end{array}$ & $\mathbf{I}_{\mathbf{f}} / \mathbf{I}_{\mathbf{b}}$ & $\begin{array}{c}\text { Onset } \\
\text { Potential } \\
(\mathbf{V})\end{array}$ \\
\hline $\mathrm{G} / \mathrm{Pt}$ & 24 & 239 & 11 & 0.77 & 0.26 \\
\hline $\mathrm{G} / \mathrm{Pt}_{3}-\mathrm{Ni}_{1}$ & 9 & 330 & 41 & 0.84 & 0.17 \\
\hline $\mathrm{G} / \mathrm{Pt}_{2}-\mathrm{Ni}_{1}$ & 17 & 428 & 26 & 0.79 & 0.23 \\
\hline $\mathrm{G} / \mathrm{Pt}_{1}-\mathrm{Ni}_{1}$ & 10 & 434 & 46 & 0.94 & 0.17 \\
\hline
\end{tabular}

The G/Pt3-Ni1 and G/Pt1-Ni1 exhibited the same onset potential, i.e. 0.17 $\mathrm{V}$ (vs. Ag/AgCl, Fig. 6b), which have a negative shift of $\sim 0.06 \mathrm{~V}$ and $0.09 \mathrm{~V}$ compared with those of G/Pt2-Ni1 $(\sim 0.23 \mathrm{~V})$ and G-Pt $(\sim 0.26 \mathrm{~V})$, respectively. That suggests a higher catalytic activity and an easier MOR proceeding on the surface of $\mathrm{G} / \mathrm{Pt}_{3}-\mathrm{Ni}_{1}$ and $\mathrm{G} / \mathrm{Pt}_{1}-\mathrm{Ni}_{1}$ nanocatalysts compared to the others.

\section{Chronoamperometry (CA)}

The stability of nanocatalysts was tested by amperometric measurement under a constant potential of $0.72 \mathrm{~V}$ for $3600 \mathrm{~s}$. All catalysts display current decrease rapidly at the initial stage (Fig. 7). This is attributed to the formation of intermediate species such as $\mathrm{CO}_{\text {ads }}$ and $\mathrm{CHO}_{\text {ads }}$ during $\mathrm{MOR}$. However, the anodic current density of $\mathrm{G} / \mathrm{Pt}_{1}-\mathrm{Ni}_{1}$ nanocatalyst is the highest during the time range, indicating that $\mathrm{G} / \mathrm{Pt}_{1}-\mathrm{Ni}_{1}$ has excellent electrocatalytic stability toward MOR, a better tolerance to the intermediate species, which make it a favorable material as anode for DMFCs.

The improved catalytic activity of G/Pt-Ni nanocatalysts can be explained based on the synergistic action of $\mathrm{Pt}$ and $\mathrm{Ni}$ in the catalysts, also on the change of electronic properties of $\mathrm{Pt}$ which takes place by the presence of $\mathrm{Ni}$ in the catalysts. The geometric environment and atomic configuration of the $\mathrm{Pt}$ atoms in Pt-Ni catalysts is changed due to the formation of an alloy with Ni. This

Egypt. J. Chem. 58, No. 4 (2015) 
change may affect the electronic structure of $\mathrm{Pt}^{(31,32)}$, leading to an alteration in the electrocatalytic activities toward MOR. Another study showed that when Ni alloyed with $\mathrm{Pt}$, the electronic structure of Pt modifies due to the charge transfer from Ni to Pt, leading to a lower density of states at the Fermi level ${ }^{(33)}$, reduces the Pt-CO bond energy and weakens the $\mathrm{CO}$ adsorption on Pt-Ni catalysts ${ }^{(34,35)}$. Therefore, the electrocatalytic activity of $\mathrm{Pt}-\mathrm{Ni}$ catalysts is improved.

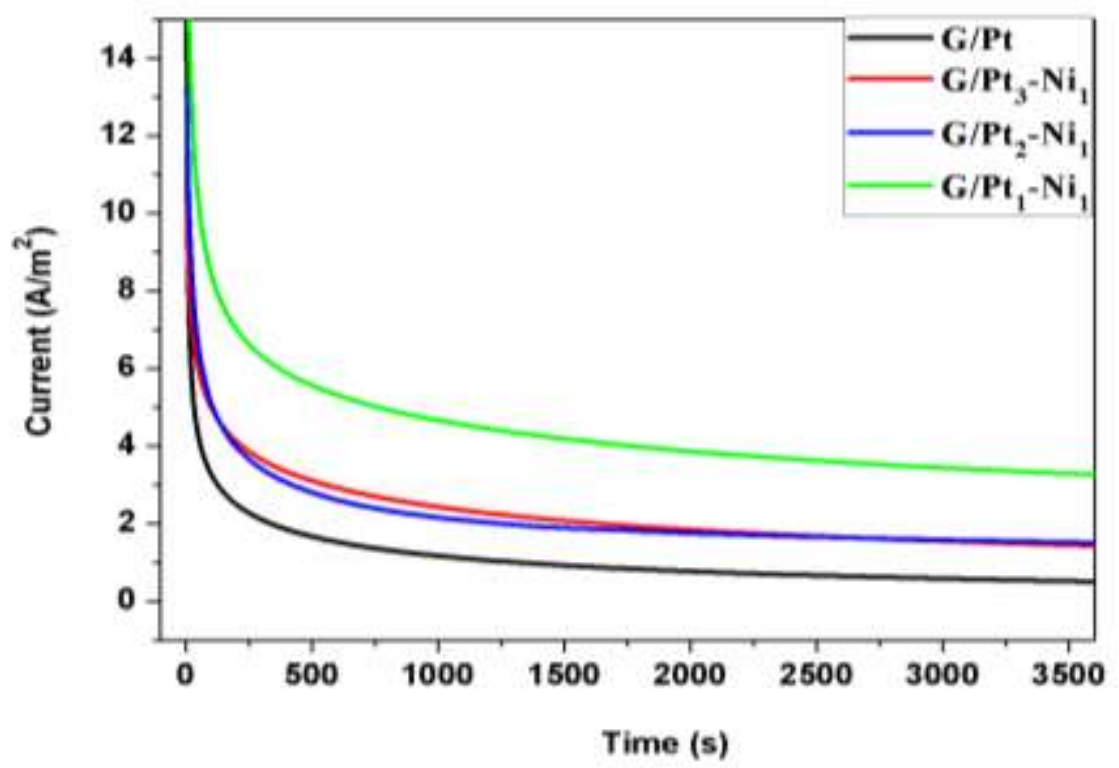

Fig. 7. Amperometric i-t curves of $\mathrm{G} / \mathrm{Pt}, \mathrm{G} / \mathrm{Pt}_{3}-\mathrm{Ni}_{1}, \mathrm{G} / \mathrm{Pt}_{2}-\mathrm{Ni}_{1}$, and $\mathrm{G} / \mathrm{Pt}_{1}-\mathrm{Ni}_{1}$ catalysts in $0.5 \mathrm{M} \mathrm{H}_{2} \mathrm{SO}_{4}$ containing $1 \mathrm{M} \mathrm{CH} 3 \mathrm{OH}$ at $0.72 \mathrm{~V}$.

The methanol oxidation takes place via major steps of methanol adsorption, successive dehydrogenation to intermediates (e.g., $\mathrm{CO})$ and $\mathrm{CO}$ oxidation to the final product of $\mathrm{CO}_{2}{ }^{(36-37)}$. Pt provides adsorption sites and activates the $\mathrm{C}-\mathrm{H}$ bond cleavage of the adsorbed methanol. During this process, the Pt-CO species is formed and is strongly adsorbed onto the Pt surface, blocking the active sites for methanol adsorption and inhibiting the oxidation of methanol. For Pt-Ni alloy catalysts, the nickel hydroxide species, which exists on the surface of the catalyst ${ }^{(33)}$, may offer $\mathrm{OH}$ species to remove the intermediate $\mathrm{CO}$ and reproduce the $\mathrm{Pt}$ activate sites for methanol adsorption ${ }^{(38)}$.

\section{Conclusion}

In summary, different Pt-Ni catalysts supported on graphene were successfully synthesized using a simple one-step polyol method. The reduction of GO to graphene and doping of $\mathrm{Pt}-\mathrm{Ni}$ nanoparticles on graphene were attained simultaneously in ethylene glycol. The synthesized Pt-Ni alloy nanoparticles supported on graphene sheets were highly dispersed and the particle size was about 1-3 nm. The electrochemical activities investigated by CV and CA exhibited

Egypt. J. Chem. 58, No. 4(2015) 
promising results. The $\mathrm{G} / \mathrm{Pt}_{3}-\mathrm{Ni}_{1}, \mathrm{G} / \mathrm{Pt}_{2}-\mathrm{Ni}_{1}$ and $\mathrm{G} / \mathrm{Pt}_{1}-\mathrm{Ni}_{1}$ catalysts showed higher specific activity than that of G/Pt. Their values were 41, 26, 46 and 11 $\mathrm{A} / \mathrm{m}_{\mathrm{Pt}}^{2}$, respectively. Also, their mass activities $(\%)$ were $138,179,181$, and 100 , respectively. The $\mathrm{G} / \mathrm{Pt}_{1}-\mathrm{Ni}_{1}$ catalyst showed the highest electrocatalytic activity and stability toward MOR, a better tolerance to the intermediate species and favors long-term application as the anode material for DMFCs.

Acknowledgements: This work was financially supported by the Academy of Scientific Research and Technology (ASRT) through Scientists for Next Generation Program (SNG). The authors are grateful for helpful and useful discussions by Dr. Ehab N. El Sawy.

\section{References}

1. Da Rosa A.V., Fundamentals of Renewable Energy Processes. Elsevier Inc569-623. (2009).

2. Kang, Y. and Murray CB., Synthesis and electrocatalytic Properties of cubic Mn-Pt nanocrystals (nanocubes). Am. Chem. Soc. 132, 7568-9 (2010).

3. Yue, Q., Zhang, K., Chen, X., Wang, L., Zhao, J. and Liu, J, et al., Generation of $\mathrm{OH}$ radicals in oxygen reduction reaction at Pt-Co nanoparticles supported on graphene in alkaline solutions. Chem. Commun. (Camb). 46 (19), 3369-71 (2010).

4. Hwang, S.J., Yoo, S.J., Jang, S., Lim, T.H., Hong, S.A., and Kim, S.K. Ternary Pt$\mathrm{Fe}-\mathrm{Co}$ alloy electrocatalysts prepared by electrodeposition: Elucidating the roles of $\mathrm{Fe}$ and co in the oxygen reduction reaction. J. Phys. Chem. C. 115 (5), 2483-8 (2011).

5. Wang, D., Xin, H.L., Yu, Y., Wang, H., Rus, E. and Muller, D.A., et al., Ptdecorated PdCo@Pd/C core-shell nanoparticles with enhanced stability and electrocatalytic activity for oxygen reduction reaction. Am. Chem. Soc. 132 (50), 12 (2010).

6. Mu, R., Fu, Q., Xu, H., Zhang, H., Huang, Y. and Jiang, Z., et al., Synergetic effect of surface and subsurface Ni species at $\mathrm{Pt}$ - Ni bimetallic catalysts for $\mathrm{CO}$ oxidation. Am. Chem. Soc. 133, 1978-86 (2011).

7. Loukrakpam, R., Luo, J., He, T., Chen, Y., Xu, Z. and Njoki, P.N., Nanoengineered PtCo and PtNi catalysts for oxygen reduction reaction: An assessment of the structural and electrocatalytic properties. The Journal of Physical Chemistry C 115.5, 1682-1694 (2011).

8. Wang, Y.S., Yang, S.Y., Li, S.M, Tien, H.W., Hsiao, S.T. and Liao WH, et al., Three-dimensionally porous graphene carbonnanotube composite supported PtRu catalysts with an ultrahigh electrocatalytic activity for methanol oxidation. Electrochim. Acta, 87, 261-9 (2013).

9. Li, L. and Xing, Y., Pt-Ru nanoparticles supported on carbon nanotubes as methanol fuel cell catalysts. J. Phys. Chem. C. American Chemical Society, 111(6), 2803-8 (2007).

Egypt. J. Chem. 58, No. 4 (2015) 
10. Chen, W., Kim, J., Sun, S. and Chen, S., Composition effects of FePt alloy nanoparticles on the electro-oxidation of formic acid. Langmuir. 23 (22), 11303-10 (2007).

11. Wasmus, S. and Küver, A., Methanol oxidation and direct methanol fuel cells: A selective review. J. Electroanal. Chem. 461 (1-2),14-31 (1999).

12. McNicol, B., Rand, D.A. and Williams, K., Direct methanol-air fuel cells for road transportation. J. Power. Sources, 83 (1-2), 15-31 (1999).

13. Ren, X., Zelenay, P., Thomas, S., Davey, J. and Gottesfeld, S., Recent advances in direct methanol fuel cells at Los Alamos National Laboratory. J. Power Sources. 86 $(1-2), 111-6(2000)$.

14. Choi, S.I.I., Choi, R., Han, S.W. and Park, JT., Shape-controlled synthesis of Pt3Co nanocrystals with high electrocatalytic activity toward oxygen reduction. Chem - A Eur. J. 17(44), 12280-4 (2011).

15. Santiago, E.I., Varanda, L.C. and Villullas, H.M., Carbon-supported Pt-Co catalysts prepared by a modified polyol process as cathodes for pem fuel cells. J. Phys. Chem C. American Chemical Society, 111(7), 3146-51 (2007).

16. Bang, J.H., Han, K., Skrabalak, S.E., Kim, H. and Suslick, K.S., Porous carbon supports prepared by ultrasonic spray pyrolysis for direct methanol fuel cell electrodes. J. Phys. Chem. C. 111(29), 10959-64 (2007).

17. Bessel, C.A., Laubernds, K., Rodriguez, N.M. and Baker, R.T.K., Graphite nanofibers as an electrode for fuel cell applications. J. Phys. Chem. B. 105 (6), 11158 (2001).

18. Yoo, E., Okada, T., Kizuka, T. and Nakamura, J., Effect of carbon substrate materials as a Pt-Ru catalyst support on the performance of direct methanol fuel cells. J. Power Sources, 180 (1), 221-6 (2008).

19. Lv, R., Cui, T., Jun, M.S., Zhang, Q., Cao, A., Su, D.S., et al. Open-ended, Ndoped carbon nanotube-graphene hybrid nanostructures as high-performance catalyst support. Adv. Funct. Mater. 21(5), 999-1006 (2011).

20. Zhou, Y-G., Chen, J-J., Wang, F., Sheng, Z-H. and Xia, X-H., A facile approach to the synthesis of highly electroactive Pt nanoparticles on graphene as an anode catalyst for direct methanol fuel cells. Chem. Commun. (Camb). 46 (32), 5951-3 (2010) .

21. Hu, Y., Zhang, H., Wu, P., Zhang, H., Zhou, B. and Cai, C., Bimetallic Pt-Au nanocatalysts electrochemically deposited on graphene and their electrocatalytic characteristics towards oxygen reduction and methanol oxidation. Phys. Chem. Chem. Phys. 13 (9), 4083-94 (2011).

22. Xiong, B., Zhou, Y., Zhao, Y., Wang, J., Chen, X. and O'Hayre, R, et al., The use of nitrogen-doped graphene supporting Pt nanoparticles as a catalyst for methanol electrocatalytic oxidation. Carbon N Y. 52, 181-92 (2013). 
23. Lee, S.H., Kakati, N., Jee, S.H., Maiti, J. and Yoon YS., Hydrothermal synthesis of PtRu nanoparticles supported on graphene sheets for methanol oxidation in direct methanol fuel cell. Mater Lett. 65 (21-22), 3281-4 (2011).

24. Zhao, Y., Zhou, Y., Xiong, B., Wang, J., Chen, X. and O'Hayre, R., et al. Facile single-step preparation of $\mathrm{Pt} / \mathrm{N}$-graphene catalysts with improved methanol electrooxidation activity. J. Solid State Electrochem. 17(4),1089-98 (2013).

25. Hu, Y., Wu, P., Zhang, H. and Cai, C., Synthesis of graphene-supported hollow Pt$\mathrm{Ni}$ nanocatalysts for highly active electrocatalysis toward the methanol oxidation reaction. Electrochim Acta. 85, 314-21 (2012).

26. Xu, X., Zhou, Y., Lu, J., Tian, X., Zhu, H. and Liu, J., Single-step synthesis of $\mathrm{PtRu} / \mathrm{N}$-doped graphene for methanol electrocatalytic oxidation. Electrochim Acta. 120, 439-51 (2014).

27. Jeon, M.K., Lee, K.R., Daimon, H., Nakahara, A. and Woo, S.I., Pt45Ru45M10/C $(\mathrm{M}=\mathrm{Fe}, \mathrm{Co}$, and $\mathrm{Ni}$ ) catalysts for methanol electro-oxidation. Catal Today. 132 (1-4), $123-6$.

28. Yen, C.H., Shimizu, K., Lin, Y.Y., Bailey, F., Cheng, I.F. and Wai, C.M., Chemical fluid deposition of Pt-based bimetallic nanoparticles on multiwalled carbon nanotubes for direct methanol fuel cell application. Energy and Fuels, 21 (4), 2268-71 (2007).

29. Ghosh, S. and Raj, C.R., Facile in situ synthesis of multiwall carbon nanotube supported flowerlike pt nanostructures: An efficient electrocatalyst for fuel cell application. J. Phys. Chem. C. 114 (24), 10843-9 (2010).

30. Lin, Y., Yen, X.C.H. and Wai, C.M., PtRu / carbon nanotube nanocomposite synthesized in supercritical fluid : a novel electrocatalyst for direct methanol fuel cells ptru/carbon nanotube nanocomposite synthesized in supercritical fluid: A novel electrocatalyst for direct methanol fuel cell. Synthesis (Stuttg). 21, 11474-9 (2005).

31. Stamenkovic, V.R., Fowler, B., Mun, B.S., Wang, G., Ross, P.N. and Lucas, C.A., et al., Improved oxygen reduction activity on Pt3Ni(111) via increased surface site availability. Science, 315 (5811), 493-7 (2007).

32. Kitchin, J.R., Nørskov, J.K., Barteau, M.A., Chen, J.G., Modification of the surface electronic and chemical properties of $\mathrm{Pt}(111)$ by subsurface $3 \mathrm{~d}$ transition metals. J. Chem. Phys. 120 (21), 10240-6 (2004).

33. Xu, Z., Zhang, H., Zhong, H., Lu, Q., Wang, Y. and Su, D., Effect of particle size on the activity and durability of the $\mathrm{Pt} / \mathrm{C}$ electrocatalyst for proton exchange membrane fuel cells. Appl. Catal. B Environ. 111-112, 264-70 (2012).

34. Ishikawa, Y., Liao, M.S. and Cabrera, C.R., Oxidation of methanol on platinum, ruthenium and mixed Pt-M metals $(\mathrm{M}=\mathrm{Ru}, \mathrm{Sn})$ : A theoretical study. Surf Sci. 463 (1), 66-80 (2000). 
35. Jiang, Q., Jiang, L., Hou, H., Qi, J., Wang, S. and Sun, G., Promoting effect of Ni in PtNi bimetallic electrocatalysts for the methanol oxidation reaction in alkaline media: Experimental and density functional theory studies. J. Phys. Chem. C. 114 (46), 19714-22 (2010).

36. Spendelow, J.S., Goodpaster, J.D., Kenis, P.J.A. and Wieckowski A., Methanol dehydrogenation and oxidation on $\mathrm{Pt}(111)$ in alkaline solutions. Langmuir. 22 (25), 10457-64 (2006).

37. Spendelow, J.S., Lu, G.Q., Kenis, P.J.A. and Wieckowski., A., Electrooxidation of adsorbed $\mathrm{CO}$ on Pt (111) and Pt (111)/ Ru in alkaline media and comparison with results from acidic media. J. Electroanal. Chem. 568, 215-24 (2004).

38. Xu, C., Shen, P.K., Ji, X., Zeng, R. and Liu, Y., Enhanced activity for ethanol electrooxidation on Pt-MgO/C catalysts. Electrochem Commun. 7 (12), 1305-8 (2005).

(Received 15/ 6/2015;

accepted 13/7/2015) 


\section{حفازات كهربية نانومتريه كأقطاب أنودية في خلايا وقود الميثانول

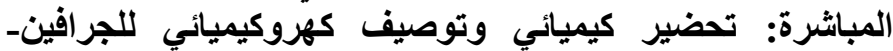 بلاتينوم-نيكل

$$
\begin{aligned}
& \text { صفاء الثريف ، محمود زورة"، نبيل المناخلي، فاطمة طاهر**، ريهام خطاب؛، } \\
& \text { و ماجده الفص *" } \\
& \text { قسم الكيمياء الفيزيقية ، ققسم الحر اريات و السير اميك و **قسم الكيمياء ـ كلية العلوم }
\end{aligned}
$$

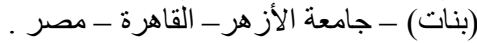

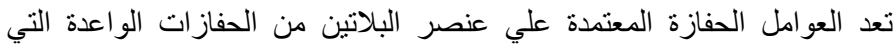

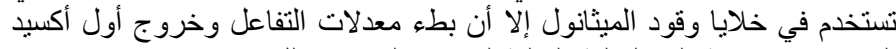

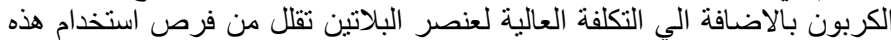
الخلايا.

في هذه الدراسة استخدمت طريقة البوليول ذات الخطوه الوحيدة البسيطة

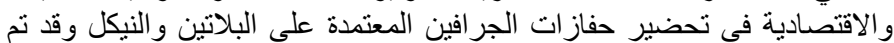

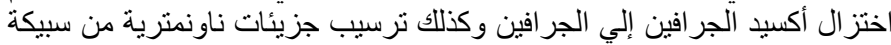

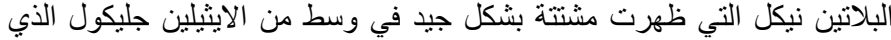

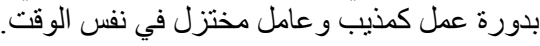

كنلك فإن الدراسة تظهر تحضير أربعة انواع من الحفاز ات التي تحتوي علي كميات مختلفة من النيكل مثل (G/Pt, G/Pt1-Ni1, G/Pt2-Ni1 and G/Pt3-Ni1).

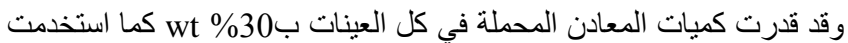

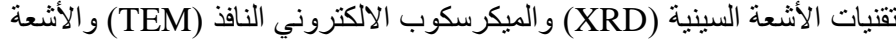

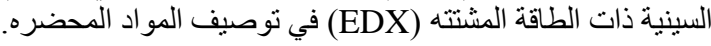

كما استخدمت تقنية الفولتماترية الدائرية والكرونوامبيرومتري في تعيين

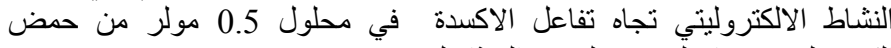
الكبريتيك محتويا علي 1 مولر من الميثانول. تفاعل الاكين.

وقد أظهرت مادة الجرافين-بلاتينوم- نيكل نشاطا كمبا ونوعيا بصورة هائله

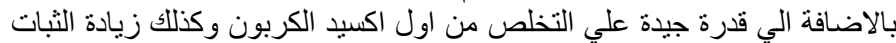
تجاه تفاعل اكسدة الميثانول مقارنة بالجة الفئ الفين -بلاتينوم.

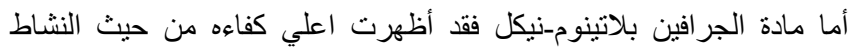

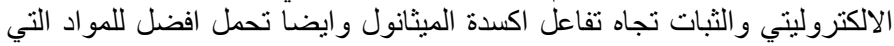

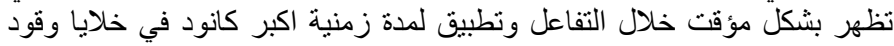

